University of Nebraska - Lincoln

DigitalCommons@University of Nebraska - Lincoln

Faculty Publications, Department of Psychology

Psychology, Department of

2007

\title{
Elder Research: Filling an Important Gap in Psychology and Law
}

Eve M. Brank

University of Nebraska-Lincoln, ebrank2@unl.edu

Follow this and additional works at: https://digitalcommons.unl.edu/psychfacpub

Part of the Psychiatry and Psychology Commons

Brank, Eve M., "Elder Research: Filling an Important Gap in Psychology and Law" (2007). Faculty

Publications, Department of Psychology. 389.

https://digitalcommons.unl.edu/psychfacpub/389

This Article is brought to you for free and open access by the Psychology, Department of at DigitalCommons@University of Nebraska - Lincoln. It has been accepted for inclusion in Faculty Publications, Department of Psychology by an authorized administrator of DigitalCommons@University of Nebraska - Lincoln. 
Published in Behavioral Sciences and the Law 25: 701-716 (2007). Published online in Wiley InterScience (www.interscience.wiley.com). Copyright 2007, John Wiley \& Sons, Ltd. DOI: 10.1002/bsl.780. Used by permission.

\title{
Elder Research: Filling an Important Gap in Psychology and Law
}

\author{
Eve M. Brank, J.D., Ph.D. (ebrank2@unl.edu) \\ University of Nebraska-Lincoln (formerly, University of Florida)
}

The author thanks Adam Brank, Candace Cabey, Drew Core, Ashley Kolnes, Isabella Valcarcel, and Orli Zaprir for their assistance with this article.

In the past few decades, psychology-law as a discipline has made great strides in understanding and guiding public policies on issues related to eyewitnesses, confessions, juries, judges, juveniles, the mentally ill, and many others. As a field, we have largely neglected the oldest subset of the population, with only a few scholars focusing specifically on elder issues or systematically including elders in their studies. The current article is a call to research. It first outlines why elders should be considered as a specific subset of the population even though they have not been an area of focus in the field. Second, the article provides suggestions for integrating elder issues into more common psychology-law research as well as some new areas for research.

\section{Law-Psychology's Place in Elder Research Issues}

In the United States, medical and safety advancements have resulted in an average life span of approximately 78 years (Arias, 2006), which is about ten years longer than it was in the 1950s (National Center for Health Statistics, 2005). Although "old age" may have a later onset than it did comparatively recently, does age (specifically advanced age) create unique needs and issues? Gerontological scholars certainly posit that it does (Lowenstein, 2004), but it is unclear how great an effect this should have on other scholarly areas. The current article examines whether, and how, law-psychology as a discipline should be considering elder issues within the more conventional legal psychology topic areas and within new areas that are specific to this population.

The term elder has generally been used to refer to people who are aged 65 or older. Some speculate that the age of 65 was originally chosen as part of the German national pension system because it was unlikely that many people would reach that chronological landmark (Roebuck, 1979). Now that many people reach and exceed 65, it is unclear whether it should be considered an important milestone for the purposes of defining "elderly." Even organizations that focus on the needs of the elderly are not especially forthright in defining age-appropriate participants. In the medical field, the American Geriatrics Society states it is "Dedicated to the health of older Americans" (emphasis added; see http://www. 
americangeriatrics.org/). The National Academy of Elder Law Attorneys has the mission of enhancing the lives of people as they age (emphasis added, see http:/ / www.naela.com/). The Department of Health and Human Services Administration on Aging seems to define older Americans as those 65 years and over in some documents (Snapshot, 2003), but describes the elderly as 60 years and over in other places (Fact Sheet, 2003). To simplify for this article, the term elder will generally refer to those over 65 years of age; however, it is clear that the definition of elderly is much more fluid and may be in need of some standardization.

\section{The Elder Body and Mind}

No matter how one defines "elder," physical and cognitive differences clearly emerge as a person ages. Non-pathologic changes such as graying of the hair are easily visible (Warner, 2003), and aging is an independent risk factor for a number of prominent medical problems including heart disease, cancer, osteoporosis, and many others (Amant et al., 2005; Chun \& McGee, 2004; Wilkins \& Birge, 2005). Vision and hearing disorders are also more common in the elderly. Even blindness can occur as a result of cataracts, glaucoma, diabetic retinopathy, and macular degeneration, which all occur more frequently as a person ages (Brodie, 2003). In a national health survey, $11 \%$ of $55-64$ year old respondents and $30.3 \%$ of 85 year old and older respondents reported some form of vision impairment (Schoenborn, Vickerie, \& Powell-Griner, 2006). In the same survey, hearing impairment was reported by $22.3 \%$ of the $55-64$ year olds and rose to $58 \%$ for the 85 and older respondents (Schoenborn et al., 2006). Somewhat surprising, however, is the infrequence of hearing aid use for those who have hearing impairment. Approximately $60 \%$ of older Americans report not using a hearing aid even though they have significant hearing loss (Popelka et al., 1998).

Cognitive abilities are also altered in the aging process. Intelligence, intellectual skills, and memory all change. Although crystallized intelligence (knowledge a person has) remains unchanged or may even improve, fluid intelligence (ability to solve novel problems without any prior training) declines (Stuart-Hamilton, 2003, but see Beier \& Ackerman, 2005). Research has also demonstrated that intellectual skills, such as attention, are negatively affected by the aging process. Task complexity, such as dividing the participant's attention, exaggerates the differences between younger and older adults (McDowd \& Craik, 1988).

Both short-and long-term memory present signs of deterioration in old age (Stuart-Hamilton, 2003). Short-term memory studies involving recall of items immediately or within less than a 30-second delay demonstrate a negative relationship with age (Charatan, 1978; Craik, Anderson, Kerr, \& Li, 1995). The differences are exaggerated when the tasks are more complex (Morris, Gick, \& Craik, 1988). Working memory is also affected as evidenced by the fact that elders demonstrate more difficulties with activities such as reading a passage of text (Stuart-Hamilton, 2003). Some research even suggests that an elder's speech and writing becomes simplified because of age effects (Kemper, 1988, but see Boone, 2000). Memory changes are well known and may even be inflated by elder self-report. In fact, older participants in the study by Parkin and Walter (1992) were significantly less confident about their abilities even when they were correct in the memory task. Vividness of autobiographical memories also declines with age (Nigro \& Neisser, 
1983) as does prospective memory (Maylor, 1998), which is defined as the memory that enables a person to remember to do something as part of a set of ongoing cognitive tasks. Fortunately, memory aids, such as writing down information (Hartley, 2002) or the innovative use of personal digital assistants (PDAs) with elders (Sterns, 2005), can often ameliorate the impact of some of these changes.

The aforementioned declines in cognition are generally present for all persons as they age (Gatz, 2006), but these deficits do not occur in the same manner and at the same rate for all (Jarvik \& Small, 2000). The decline occurs more rapidly and aggressively when certain disorders are present. In fact, all forms of dementia, a generic term used to describe cognitive and behavioral disorders caused by chronic brain disease, are more common in elderly people (Neary \& Snowden, 2003). Probably the best known form of dementia, Alzheimer's disease, is more likely to occur as a person ages.

Medical research demonstrates that elders are physically and cognitively different from non-elders and that the process of aging creates vulnerabilities in a person's body and mind that increases the risks of injury, illness, and ultimately death (Miller, 1999). Even with these differences, most elderly still function within normal levels of cognition (Dunkin \& Kasl-Godley, 2000) and are still actively involved in society (Jarvik \& Small, 2000). The combined effect results in a need to consider the elderly as a distinct subset of the population for the purposes of research, specifically legal psychology research.

\section{Legal Psychology's Attention to Elder Issues}

It would be patently incorrect to say that legal psychologists have entirely neglected elder issues. A number of well respected scholars in law-psychology or closely related areas have devoted a great deal of research effort to this topic and have advocated for more research (for examples, see Baker, Perr, \& Yesavage, 1986; Bonnie \& Wallace, 2002; Golding, Allen, Yozwiak, Marsil, \& Kinstle, 2005; Hafemeister, 1999; Rothman, Dunlop, \& Entzel, 2000a; Yarmey, 1984). Elder issues still represent an understudied area of focus.

Recently, Wiener and his colleagues (2002) described the state of the discipline by evaluating published papers in one law-psychology journal. In that evaluation, the authors aptly noted the deficits in minority and gender focused research; however, participant age (beyond college sample versus community sample) went unexamined as a factor. To confirm that this omission was not just a reflection of the authors' interests, a search of the PsychINFO database was conducted to examine the same journal (Law and Human Behavior). From 1979 to the present there have been close to 900 articles published in Law and Human Behavior. Fifty-six articles reported having participants in the age categories of 65 and older ("old") and/or 85 and older ("very old") (as defined in the PsychINFO limiters); however, most of those articles were not specifically on the topic of elders, but only included some participants within the two age ranges specified. Using a variety of search terms, similar patterns emerged. Only one article had the term "elder abuse" in its abstract, but 23 have been published about child abuse. Similarly, 44 articles have "age differences" as one of their subject terms, Of these, 29 were about children. The other 15 mostly examined age differences between college student samples and non-college student samples. 
For Behavioral Sciences and the Law, about 800 articles have been published since 1983. Forty-six of these articles reported including participants 65 years of age or older. Two articles are about elder abuse, in contrast to 43 that are about child abuse. Using "age differences" as a subject term yielded 14 articles, with only 2 relating to elder issues and virtually the rest focusing on juveniles.

Textbook attention to the topic confirms these informal journal statistics. Again, a search of a few of the well respected Psychology and Law textbooks revealed only minor, if any, attention to the topic of elders. For instance, in the text by Greene, Heilbrun, Fortune, and Nietzel (2007), the index provides no entries for the terms elder, age, older, or seniors. In contrast, the most recent edition of this text includes an entire chapter on children and the specific issues relevant to them in psychology and law. In the text by Bartol and Bartol (2004), no entries are present for the terms referring to elders. Five main entries begin with "child" and approximately 20 subentries do also. A similar pattern emerges in the texts by Horowitz, Willging, and Bordens (1998) and Kapardis (2003). Some attention is given in several of the texts to the differences between elder and non-elder eyewitnesses, but otherwise elder issues appear not to be included.

Despite some interest, elder issues have not received the same amount of consideration that other age groups, specifically children, have received. But, does it matter? Even though elder issues are not well represented, the journal articles and textbooks are covering very important and diverse topics. Children's issues are of obvious importance; however, given changing demographics, and the growing presence of elders in the legal system, and if we desire to have an impact and address the issues that are relevant in today's legal culture (Ogloff, 2002), then elder issues must be addressed by the psychology and law field on a much grander scale. The elder subpopulation is the fastest growing age group in the United States, they are more active in all areas of society, including the legal system (Flynn, 2000), and they have specific legal needs (Golding, Yozwiak, Kinstle, \& Marsil, 2005; Kapp, 2006). Combining this information with the cognitive and physical differences, it is clear that elders present distinct needs that deserve specific attention.

The rest of this article discusses how cognitive and physical differences in elders versus non-elders could influence well established psychology-law research, clinical, and legal principles. First, eyewitness testimony research will be examined with specific attention to the needs of elder witnesses. Second, the willingness, abilities, and effects of elders serving on juries are discussed. Third, issues involving elder victims and defendants are examined, including courtroom accommodations. Competency in medical decision making is then discussed, and finally care giving of the elderly will be examined.

\section{Eyewitnesses}

Research has generally demonstrated that eyewitnesses of any age are not particularly skilled at making accurate identifications. Event-related stress (Deffenbacher, Bornstein, Penrod, \& McGorty, 2004) and the procedures for lineups or photo spreads (Wells \& Olson, 2002) are some of the factors that influence eyewitness abilities and accuracy (for a review see Lindsay, Brigham, Brimacombe, \& Wells, 2002). The elderly have additional physical and cognitive burdens (detailed 
above) that can influence their accuracy as eyewitnesses. Research that compares younger adults to older adults has demonstrated that elder witnesses are less accurate (Bartlett \& Fulton, 1991; Bornstein, Witt, Cherry, \& Greene, 2000; Brimacombe, Quinton, Nance, \& Garrioch, 1997; Brimacombe, Jung, Garrioch, \& Allison, 2003; O'Rourke, Penrod, Cutler, \& Stuve, 1989), more often misled by false information (Cohen \& Faulkner, 1989; but see Bornstein et al., 2000), and have greater false recollection (Schacter, Koutstaal, Johnson, Gross, \& Angell, 1997). Their testimony may result in fewer guilty verdicts with mock jurors, especially when the elders are described in stereotypical ways (Bradshaw, Golding, \& Marsil, 2006; Nunez, McCoy, Clark, \& Shaw, 1999; but see Ross, Dunning, Toglia, \& Ceci, 1990). Other research involving eyewitnesses has found that the older eyewitnesses are viewed as more honest (Allison, Brimacombe, Hunter, \& Kadlec, 2006; Ross et al., 1990) or no age effects are found (Neuschatz et al., 2005), especially when the elder has normal vision, hearing, and cognition (Smith \& Winograd, 1978; Yarmey, 1984). Clearly, witness researchers have focused on the elderly (Bornstein, 1995) and it is probably the best example of incorporating elder issues into legal psychology research, but there is still much to be learned. In fact, when researchers give age effects attention, it has traditionally been more focused on the very young rather than the very old (Wells, Wright, \& Bradfield, 1999). For this reason, the children's witness literature could provide some future directions for elder witness research.

During the past few decades, child witness issues have gained the attention of top psychology-law scholars (Goodman, 2006). For example, this line of research has investigated the completeness, accuracy, suggestibility, and reliability of children's testimony (see Quas, Goodman, Ghetti, \& Redlich, 2000, for a review). Might the elderly also have similar recall difficulties and needs? Medical research suggests a correspondence not only because of the degeneration of elder memory (Stuart-Hamilton, 2003), but also the diffidence many elders experience about their own memory abilities (McDougall, 2004; Parkin \& Walter, 1992). Compounding this, some scholars have posited that the elders' general high regard for the legal system makes them more susceptible to a wish to please authorities, independent of actual witness knowledge (Yarmey, 2000).

Although elders may experience a variety of difficulties as witnesses, opportunities for an elder to be a witness have recently increased. Elder maltreatment, one area where an elder might be both a victim and a witness, has reached record proportions (Moskowitz, 1998; Wolf, 2000), though it is still believed to be underreported (Breaux \& Hatch, 2003). The effects of testifying in court can be quite difficult for some children, especially victims of sexual abuse (Goodman, Taub, Jones, \& England, 1992), yet we know considerably less about the effects of testifying on elderly abuse victims. This is an example of a potentially rich area for research.

\section{Jurors}

Jurors are a very common population of interest for psychology-law research (Greene et al., 2002; Wiener et al., 2002), but little work has been done on elders as jurors. For instance, little is known about the representation of elders on juries because many states do not collect age information about their jury panels (Entzel, Dunlop, \& Rothman, 2000). Anecdotally, it would seem as though the young 
elders (age 65-74) would be more likely to serve as jurors because of their greater time availability (Entzel et al., 2000) and their more positive attitudes toward jury service (Boatright, 2001), but a number of states excuse elders from jury service (Adams, 2000). For instance, in Florida, a state with a large elder population, a person 70 years of age or older will be excused from jury service upon request (Persons disqualified or excused from jury service, 2006). As the population average age inches upward and "30 becomes the new 20" (Tierney, 2004), will 70 be the new 60 ? Does the presumption of disability these age exemption statutes imply reflect the current status of elders? (See Flynn, 2000, for a discussion of the "new gerontology.")

Another question is whether attorneys will attribute age-based stereotypes to elders when they select their jury (Entzel et al., 2000). The US Supreme Court has held that attorneys cannot use their peremptory challenges to remove potential jurors based on race (Batson v. Kentucky, 1986) or gender ( J.E.B. v. Alabama, 1994), but there are no similar restrictions for age (Entzel et al., 2000). Presumably, age can be used as a reason to exclude a potential juror even though we know very little about the influence of elders serving as jurors.

Research has produced mixed results concerning the effects of jurors' demographic characteristics on verdicts, but generally they only provide a weak or inconsistent influence in both civil and criminal cases (Greene \& Bornstein, 2003). Of course, when age is examined in jury studies it is commonly in reference to a student versus a non-student sample of mock jurors (Bornstein, 1999) and not based on comparisons of the elderly versus the non-elderly. When elders and nonelders have been compared in mock jury studies, differences do emerge (Hart, Evans, Wissler, Feehan, \& Saks, 1997). Because of their life experiences an elder can bring a different perspective into the jury room that may have wide variation of effects on the outcome of a case (Entzel et al., 2000), but the research has not been developed fully enough to make any definitive statements about the effects of elders as jurors.

In addition to representativeness, comprehension of jury instructions has garnered research attention (Greene et al., 2002), but should there be concerns specifically with elder jurors and comprehension of jury instructions? Cognitive declines such as decreases in fluid intelligence and attention (Stuart-Hamilton, 2003) could easily interfere with the ability to comprehend the instructions and research has certainly demonstrated that jurors generally lack complete comprehension of instructions (English \& Sales, 1997). For these reasons, research should actively include elders in jury studies and consider more comparison studies between elders and non-elders on comprehension of jury instructions. Such research might lead to the creation of strategies designed to increase comprehension of instructions not just for college-student samples, but community member samples that include elders.

Additionally, some practical requirements should be addressed based on the physical needs of the elderly serving as jurors. Specifically, there may be a need for large-print instructions of any written evidence that is taken into the jury room. The relatively new movement to bring visual technologies in the courtroom (Brewer, Harvey, \& Semmler, 2004; Feigenson \& Dunn, 2003) might be used to address elder issues. Similarly, considerations should be made for the large percentage of elders who are hearing impaired but do not wear a hearing aid because 
of a reluctance to admit the impairment (Popelka et al., 1998). Common physical ailments such as arthritis might also interfere with sitting for the obligatory long periods of time that jury service often entails. Although each of these physical issues might seem better addressed by a gerontology health expert, psychologylaw researchers should consider whether the special needs of the elderly might be interfering with jury service or influencing some to opt out of participation.

\section{Party to a Case}

The physical and cognitive difficulties that interfere with jury service can also interfere with an elder's access to the courts as a party in a civil and criminal case (Dunlop, Rothman, \& Entzel, 2000). Relatively minor physical changes to the courtroom could be made, such as enlarging exhibits, insuring that anyone speaking does so at a slow pace, and assuring that the different parts of the courtroom are truly accessible (Adams, 2000). In Florida, two circuits have recently developed Elder Justice Centers to address the specific needs of an elder as a party in a case (Rothman \& Dunlop, 2004), but further evaluations of their effectiveness are needed.

Although elders may not be victimized as much as once believed (Wolf, 2000), the results of victimization can be extreme because of an elder's physical frailty and because of the revictimization of going through legal processes that are not especially considerate of an elder's cognitive and physical needs. Some communities do have special police officers to address the needs of elder victims (Heisler \& Stiegel, 2002), but the system in general is not one friendly to elders (Finkel \& Macko, 2000). Both clinical and non-clinical legal psychologists could provide useful research to address the elder victim's needs much the same way as research has focused on the needs of child victims.

Elders may also become parties in a case as the criminal defendant. The elderly comparatively are very infrequently the perpetrators of crime. In fact, elder crime in general does not significantly contribute to the nation's crime rate, but as the elder population has increased so too have elder crimes (Flynn, 2000). Some have postulated that the elderly are less likely to offend because of the physical effects of aging (Flynn, 1996), but with the Internet, committing some forms of fraud and sex offenses are not as physically challenging. While elders as a group have not used the internet as frequently as adolescents and younger adults (Morrell, Mayhorn, \& Bennett, 2000), computer usage might be a generational rather than age issue.

Although criminologists have studied a few aspects of elder crime, it is still a fairly under-researched topic, and the propensities of elders to commit Internet crimes because they are less physically challenging is just one possible area of inquiry. Research could provide unique insights into this area by examining risk assessments for elder offenders and amenability to treatment that might be unique to the elders' needs.

Sentencing of elders on conviction is another under-examined area. Although it is a widely held assumption that once an elder is apprehended for a crime sentencing will be more lenient, there is little empirical evidence supporting this assumption. One exception to the dearth of research is the examination by Steffensmeier and Motivan (2000) of Pennsylvania data finding that older defendants in com- 
parison to younger were generally sentenced to probation more often than imprisonment and that elders received shorter sentences than their younger counterparts. Even shorter stays in prison may have significant effects on the elder inmate (Gallagher, 2001) and older prisoners are the fastest growing age group in prison (Kerbs, 2000a). One reason for the increase of elders in prisons is the aging of the general population, but it is also a result of more life sentences, mandated sentences (e.g. "three-strikes" laws) that are effectively life sentences, and the reduction of parole possibilities (Beiser, 1999; Wall, 1998).

As the prison population ages, geriatric care or nursing home placements (Douglass, 1991; Kerbs, 2000a) and hospice care (Yampolskaya \& Winston, 2003) become real needs of inmates, creating a severe financial impact on prisons (Dunlop et al., 2000). In fact, an older inmate often has even more complex health needs than an elder who is not within the correctional system (Kerbs, 2000a; Aday, 1994). The prison environment and other related factors not only physically age a person, but can lead to complex medical decision making issues, where aging prisoners feel they are not afforded freedom of choice in their medical care (Enders, Paterniti, \& Meyers, 2005). End-of-life decisions made in "normal" circumstances are far from straightforward, especially when a surrogate decision maker is involved (Ditto, 2006), but when this decision is made by or for an elder prisoner the process is likely to be even more complex. Those elder inmates who are released also face different challenges from their younger counterparts because of their health needs. Unfortunately, we know very little about how to address the needs of elder inmates and their post-release needs. For some, the answer is the decarceration of older prisoners (Kerbs, 2000b), but it is clear that such an undertaking will require extensive commitment from policy makers. Effective empirical research on each of these topics is imperative.

\section{Competency}

Assessing dangerousness, psychological status, and treatment options are common clinical foci in legal psychology (Weiner et al., 2002). In particular, competency, especially competency to stand trial, has been the subject of much research (Zapf, Viljoen, Whittemore, Poythress, \& Roesch, 2002). Although competency to stand trial can be an issue for elders (see the preceding section concerning elders as defendants), the more common issue of competency for the elderly involves medical decision making.

As described above, elders in general are the subset of the population with the most complex medical issues. As such, they are logically making some of the most difficult decisions regarding health care. While medical decision making by juveniles has received increasing attention (Bottoms, Reppucci, Tweed, \& Nysse-Carris, 2002), a consistent model integrating legal and psychological perspectives has yet to emerge. A similar situation exists for elder decision making and competency to make medical decisions (Moye, 2000).

Like all individuals, an elder is presumed to be competent absent clinical evidence or a legal determination to the contrary. Ordinarily, when a patient lacks competence to make medical decisions, physicians tend to defer to family members unless the person has a designated health care surrogate (Kim \& Appelbaum, 2006). In some states, state law creates a hierarchy of which family mem- 
bers should be consulted about medical decisions when the patient is incompetent to make these decisions. However, the statutory hierarchy may not represent the true desires of the patient (Kim \& Appelbaum, 2006). Research could provide important information for policy makers about alternative hierarchies, and provide additional information to the public about the importance of and need for a medical surrogate. Similarly, though the elderly are disproportionately affected by the right-to-die issue, only a limited amount of research has considered this topic (Glick, 1991). Research would be helpful in informing clinicians who are asked to conduct end-of-life evaluations to determine decision making competencies and to make recommendations based on those evaluations (Moye, 2000; Rosenfeld, 2004).

\section{Caregiver Issues}

Because of physical and cognitive declines elders often require some form of caregiving. Currently, 30 states have legislated requirements concerning filial responsibility (Pakula, 2005), with more likely to be enacted in the near future. Filial responsibility, the notion that adult children will care for their elderly parents, has an extensive history dating back to the Elizabethan Poor Relief Act of 1601. Empirical research has examined this notion mostly with regard to attitudes of and burdens placed on the caregivers (Butler, Turner, Kaye, Ruffin, \& Downey, 2005; Dellmann-Jenkins \& Brittain, 2003), with some work done on the circumstances of and motivations for caring for aging parents (Caputo, 2002; DellmanJenkins \& Brittain, 2003; Stein et al., 1998).

In previous caregiver research, the person who is the caregiver is always clearly defined; however, court cases indicate that it may not always be completely clear when a caregiving role is undertaken. For example, Theresa Sieniarecki unsuccessfully argued that she was not her mother's caregiver as defined in the pertinent statute (Definitions, 2006) because it was not clear to her that she had assumed responsibility for the care of her mother (Sieniarecki v. Florida, 2000). The Supreme Court of Florida was unsympathetic and upheld the jury's determination that as a result of Theresa's actions (or inactions) she was guilty of neglect. The court emphasized Theresa's own testimony that all the responsibility of caring for her mother fell on her (except when her brother brought chili dogs for her mother to eat) and she never called anyone for help, advice or medical care for her mother. The court reasoned it was clear that Theresa was her mother's caregiver. Although the Sieniarecki case presents both an extreme neglect situation and a fairly clear caregiver role assumed by one family member, other cases may lack clarity on these issues. No formal or written agreement between the elder's family members was necessary in Sieniarecki; instead the court made its decision on the behaviors of the elder's family. From a law-psychology perspective, is the role of caregiver as clear as the Florida Supreme Court opined? In reality, taking on the task of caregiving will often come about gradually and the solidification of the role may not be immediately clear. Law-psychology researchers should investigate the common understanding of caregiving in comparison to the legal definition. In addition, research should examine the differential ways people view this role, especially considering cultural and lifestyle differences.

Beyond comparing the legal to the common definition of caregiving, research 
regarding a number of other issues related to caring for an elder is needed. For a number of caregivers, cumbersome Medicare and Medicaid regulations intervene with care giving intentions. Medicare was originally instituted in 1965 to address the cost of health care for the elderly, while Medicaid was originally intended to provide health care coverage for the poor. Because Medicaid has become a supplement to Medicare for a number of elderly needing long-term institutionalized care, the income and asset requirements of Medicaid pose complicated decisions for these "dual-eligibles" (Tenzer, 2006). In some situations, a caregiver may not be able to help as much as they would like because of the income and asset requirements that make a person Medicaid eligible; however, Takacs and McGuffey (2002) note that there sometimes might be financial benefits to in-home care giving because it could qualify as an exception to the normal transfer penalty rules if a child resides with the elder in order to avoid nursing home care.

Caregiver burden and the interventions necessary to prevent abuse and neglect should also be examined. Despite the attention that other areas of family violence have received, research on elder abuse has lagged (Kohn, 2003; Rathbone-McCuan, 2000). Much of the current emphasis is on the detection of abuse, definitions of abuse (Morgan, Johnson, \& Sigler, 2006), and reporting requirements (RathboneMcCuan, 2000) rather than prevention (Kapp, 1995). In fact, the elderly may be at even greater risk than children. In contrast to children, elders are vulnerable to financial abuse, and, in contrast to at least some cases of child abuse, no teachers will have the opportunity to observe the external signs of physical abuse. In addition, abuse could present as one of the common physical changes associated with aging (e.g. eating disorders that lead to very low weight), which can make prosecution of the abuser more problematic. In addition, caregiver stress is the most often cited factor leading to elder maltreatment (McGreevey, 2005), which may have the effect of placing some blame on the elder victim because of the stress their physical and cognitive needs create (Wolf, 2000). There is room for policy relevant research that not only addresses the legal notions of care giving, but also addresses the prevention of elder abuse without blaming the elder.

\section{Conclusion}

This article presents a small selection of topics involving elders that could be studied in the legal psychology field. Elder topics have received little attention in the major psychology-law textbooks and journals. If this is to change, researchers need to either focus on specific elder issues or be more proactive about including elders as participants in their studies. Some may argue that our discipline's choice of most researched topics has been largely guided by the availability of college students as research subjects (e.g. eyewitnesses and juries). Of course, one of the reasons for using college students is that they are more readily available than any other age group and often give a similar result as a community sample obtained much more laboriously (Bornstein, 1999; but see Sears, 1986); however, elders have not traditionally been included in the comparisons between college students and community members. The proliferation of elder day service facilities may be a good resource for research participants because the elders there are less likely to have cognitive impairments than those who are in nursing homes (National Adult Day Services Association, 2007) and they may enjoy the opportu- 
nity to participate in research activities that would be interesting and differentiate from their normal daily activities.

Why should legal psychologists get involved in elder issues? As the discipline has demonstrated in other areas, it uniquely positions us to inform policy makers, physicians, attorneys, and the public. In several places this article has compared elder issues and children issues not because elders are like children, but because there is much to be learned from the way the legal psychology research has conducted research related to children. This research provides a good model because it is an area that has done good quality work, focused on a specific age group, and influenced law and policy on children (see Bottoms et al., 2002). The same opportunity exists to influence law and policy on elders, and doing so will fill a major gap in the psychology-law field.

\section{References}

Adams, W. E. (2000). Elders in the courtroom. In M. B. Rothman, B. D. Dunlop, \& P. Entzel (Eds.), Elders, Crime, and the Criminal Justice System: Myth, Perceptions, and Reality in the 21st Century (pp. 87-103). New York: Springer.

Aday, R. H. (1994). Aging in prison: A case study of new elderly offenders. International Journal of Offender Therapy and Comparative Criminology, 38, 79-91.

Allison, M., Brimacombe, C. A., Hunter, M. A., \& Kadlec, H. (2006). Young and older adult eyewitnesses' use of narrative features in testimony. Discourse Processes, 41, $289-314$.

Amant, F., Moerman, P., Neven, P., Timmerman, D., Van Limbergen, E., \& Vergote, I. (2005). Endometrial cancer. Lancet, 366, 491-505.

Arias, E. (2006, April 19). United States Life Tables, 2003. National Vital Statistic Reports, 54(14).

Baker, F. M., Perr, I. N. \& Yesavage, J. A. (1986). An Overview of Legal Issues in Geriatric Psychiatry: Report of the American Psychiatric Association. Washington, D.C.: American Psychiatric Association.

Bartlett, J. C., \& Fulton, A. (1991). Familiarity and recognition of faces in old age. Memory and Cognition, 19, 229-238.

Bartol, C. R., \& Bartol, A. M. (2004). Psychology and Law, Theory, Research, and Application, 3rd ed. Belmont, CA: Wadsworth-Thomas.

Batson v. Kentucky, 476 U.S. 79 (1986).

Beier, M. E., \& Ackerman, P. L. (2005). Age, ability, and the role of prior knowledge on the acquisition of new domain knowledge: Promising results in a real-world learning environment. Psychology and Aging, 20, 341-355.

Beiser, V. (1999). Pensioners or prisoners. The Nation, 268(18), 28-30.

Boatright, R. G. (2001). Generation and age-based differences in attitudes towards jury service. Behavioral Sciences and the Law, 19, 285-304.

Bonnie, R. J., \& Wallace R. B. (Eds.). (2002). Panel to Review Risk and Prevalence of Elder Abuse and Neglect. Washington, DC: National Research Council.

Boone, K. B. (2000). Neuropsychological evaluation. In B. J. Sadock, \& V. A. Sadock (Eds.), Comprehensive Textbook of Psychiatry, 7th ed. (pp. 2980-2988). Philadelphia, PA: Lippincott, Williams and Wilkins.

Bornstein, B. H. (1995). Memory processes in elderly eyewitnesses: What we know and what we don't know. Behavioral Sciences and the Law, 13, 349-363.

Bornstein, B. H. (1999). The ecological validity of jury simulations: Is the jury still out? Law and Human Behavior, 23, 75-91.

Bornstein, B. H., Witt, C. J., Cherry, K. E., \& Greene, E. (2000). The suggestibility of older witness. In M. B. Rothman, B. D. Dunlop, \& P. Entzel (Eds.), Elders, Crime, and the Criminal 
Justice System: Myth, Perceptions, and Reality in the 21st Century (pp. 149-161). New York: Springer.

Bottoms, B. L., Reppucci, N. D., Tweed, J. A., \& Nysse-Carris, K. L. (2002). Children, psychology, and law: Reflections on past and future contributions to science and policy. In J. R. Ogloff (Ed.), Taking Psychology and Law Into the Twenty-First Century (pp. 61-177). New York: Kluwer-Plenum.

Bradshaw, E. E., Golding, M. A., \& Marsil, D. F. (2006, March). Perceptions of elder abuse in the courtroom: The influence of hearsay witness testimony. Poster presented at the American Psychology-Law Society Meeting, St. Petersburg, FL.

Breaux, J. B., \& Hatch, O. G. (2003). Confronting elder abuse, neglect, and exploitation: The need for elder justice legislation. Elder Law Journal, 11, 207-271.

Brewer, N., Harvey, S., \& Semmler, C. (2004). Improving comprehension of jury instructions with audio-visual presentation. Applied Cognitive Psychology, 18, 765-776.

Brimacombe, C. A. E., Jung, S., Garrioch, L., \& Allison, M. (2003). Perceptions of older adult eyewitnesses: Will you believe me when I'm 64? Law and Human Behavior, 27(5), 507-522.

Brimacombe (née Luus,) C. A. E., Quinton, N., Nance, N., \& Garrioch, L. (1997). Is age irrelevant? Perceptions of young and old adult eyewitnesses. Law and Human Behavior, 21, 619-634.

Brodie, S. E. (2003). Aging and disorders of the eye. In R. C. Tallis, \& H. M. Fillit (Eds.), Brocklehurst's Textbook of Geriatric Medicine and Gerontology, 6th ed. (pp. 735-747). London: Churchill Livingston.

Butler, S. S., Turner, W., Kaye, L. W., Ruffin, L., \& Downey, R. (2005). Depression and caregiver burden among rural elder caregivers. Journal of Gerontological Social Work, 46, 47-63.

Caputo, R. K. (2002). Adult daughters as parental caregivers: Rational actors versus rational agents. Journal of Family Economic Issues, 23, 27-50.

Charatan, F. B. (1978). The psychopathology of old age. Journal of the National Association of Private Psychiatric Hospitals, 10, 28-35.

Chun, A. A., \& McGee, S. R. (2004). Bedside diagnosis of coronary artery disease: A systematic review. American Journal of Medicine, 117, 334-343.

Cohen, F., \& Faulkner, D. (1989). Age differences in source forgetting: Effects on reality monitoring and on eyewitness testimony. Psychology and Aging, 4, 10-17.

Craik, R. M., Anderson, N. D., Kerr, S. A., \& Li, K. Z. H. (1995). Memory changes in normal ageing. In A. D. Baddeley, B. A. Wilson, \& F. N. Watts (Eds.), Handbook of Memory Disorders (pp. 211-241). Chichester, UK: Wiley.

Deffenbacher, K. A., Bornstein, B. H., Penrod, S. D., \& McGorty, E. K. (2004). A meta-analytic review of the effects of high stress on eyewitness memory. Law and Human Behavior, 28, 687-706.

Definitions. (2006). Abuse, neglect, and exploitation of elderly persons and disabled adults. Florida Statute $§ 825.101$.

Dellmann-Jenkins, M., \& Brittain, L. (2003). Young adults' attitudes toward filial responsibility and actual assistance to elderly family members. The Journal of Applied Gerontology, 22, 214-229.

Ditto, P. H. (2006). What would Terri want? On the psychological challenges of surrogate decision making. Death Studies, 30, 135-148.

Douglass, R. L. (1991). Oldtimers: Michigan's Elderly Prisoners: Michigan Older Inmate Database: Final Report. Gerontological Society of America: Washington, DC.

Dunkin, J. J., \& Kasl-Godley, J. E. (2000). Psychological changes with normal aging. In B. J. Sadock, \& V. A. Sadock (Eds.), Comprehensive Textbook of Psychiatry, 7th ed. (pp. 29802988). Philadelphia, PA: Lippincott, Williams and Wilkins.

Dunlop, B. D., Rothman, M. B., \& Entzel, P. (2000). Epilogue: Policy implications for the 21st century. In M. B. Rothman, B. D. Dunlop, \& P. Entzel (Eds.), Elders, Crime, and the Criminal Justice System: Myth, Perceptions, and Reality in the 21st Century (pp. 331-358). New York: Springer. 
Enders, S. R., Paterniti, D. A., \& Meyers, F. J. (2005). An approach to develop effective health care decision making for women in prison. Journal of Palliative Medicine, 8, 432-439.

English, P. W., \& Sales, B. D. (1997). A ceiling or consistency effect for the comprehension of jury instructions. Psychology, Public Policy and Law, 3, 381-401.

Entzel, P., Dunlop, B. D., \& Rothman, M. B. (2000). Elders and jury service: A case of age discrimination? In M. B. Rothman, B. D. Dunlop, \& P. Entzel (Eds.), Elders, Crime, and the Criminal Justice System: Myth, Perceptions, and Reality in the 21st Century (pp. 163-182). New York: Springer.

Fact Sheet. (2003). Administration on aging. US Department of Health and Human Services Administration on Aging: Washington, DC. Retrieved September 28, 2006, from http:/ / www.aoa.gov/press/fact/ fact.asp

Feigenson, N., \& Dunn, M. A. (2003). New visual technologies in court: Directions for research. Law and Human Behavior, 27, 109-126.

Finkel, S. I., \& Macko, I. J. (2000). Impact of the criminal justice process on older persons. In M. B. Rothman, B. D. Dunlop, \& P. Entzel (Eds.), Elders, Crime, and the Criminal Justice System: Myth, Perceptions, and Reality in the 21st Century (pp. 105-125). New York: Springer.

Flynn, E. E. (1996). Age and crime. In J. E. Birren (Ed.), Encyclopedia of Gerontology, 1, 353-359. San Diego: Academic Press.

Flynn, E. E. (2000). Elders as perpetrators. In M. B. Rothman, B. D. Dunlop, \& P. Entzel (Eds.), Elders, Crime, and the Criminal Justice System: Myth, Perceptions, and Reality in the 21st Century (pp. 43-83). New York: Springer.

Gallagher, E. M. (2001). Elders in prison: Health and well-being of older inmates. International Journal of Law and Psychiatry, 24, 325-333.

Gatz, M. (2006). Cognitive capacities of older adults who are asked to consent to medical treatment or to clinical research. Behavioral Sciences and the Law, 24, 465-468.

Glick, H. R. (1991). Right-to-die: State policymaking and the elderly. Journal of Aging Studies, 5, 283-307.

Golding, J. M., Allen, J., Yozwiak, J. A., Marsil, D. F., \& Kinstle, T. S. (2005a). Perceptions of elder neglect in the courtroom. Journal of Elder Abuse and Neglect, 16, 23-46.

Golding, J. M., Yozwiak, J. A., Kinstle, T. L., \& Marsil, D. F. (2005b). The effect of gender in the perception of elder physical abuse in court. Law and Human Behavior, 29, 605-614.

Goodman, G. S. (2006). Children's eyewitness memory: A modern history and contemporary commentary. Journal of Social Issues, 62, 811-832.

Goodman, G. S., Taub, E. P., Jones, D. P., \& England, P. (1992). Testifying in criminal court: Emotional effects on child sexual assault victims. Monographs of the Society for Research in Child Development, 57, v-142.

Greene, E., \& Bornstein, B. H. (2003). Determining Damages: The Psychology of Jury Awards. Washington, DC: American Psychological Association.

Greene, E., Chopra, S. R., Kovera, M. B., Penrod, S. D., Rose, V. G., Schuller, R., \& Studebaker, C. A. (2002). Jurors and juries: A review of the field. In J. R. Ogloff (Ed.), Taking Psychology and Law Into the Twenty-First Century (pp. 225-284). New York: Kluwer-Plenum.

Greene, E., Heilbrun, K., Fortune, W. H., \& Nietzel, M. T. (2007). Wrightsman's Psychology and the Legal System, 6th ed. Belmont, CA: Thomson Wadsworth.

Hafemeister, T. L. (1999). End-of-life decision making, therapeutic jurisprudence and preventive law: Hierarchical v. consensus-based decision-making model. Arizona Law Review, 41, 329-373.

Hart, A. J., Evans, D. L., Wissler, R. L., Feehan, J. W., \& Saks, M. J. (1997). Injuries, prior beliefs, and damage awards. Behavioral Sciences and the Law, 15, 63-82.

Hartley, J. (2002). Notetaking in non-academic settings: A review. Applied Cognitive Psychology, 16, 559-574.

Heisler, C. J., \& Stiegel, L. A. (2002). Enhancing the justice system's response to elder abuse: Discussions and recommendations of the "Improving Prosecution" working group of The National Policy Summit on Elder Abuse. Journal of Elder Abuse and Neglect, 14, 31-54. Horowitz, I. A., Willging, T. E., \& Bordens, K. S. (1998). The Psychology of Law: Integrations and 
Applications, 2nd ed. New York: Longman.

Jarvik, L. F., \& Small, G. W. (2000). Geriatric psychiatry: Introduction. In B. J. Sadock, \& V. A. Sadock (Eds.), Comprehensive Textbook of Psychiatry, 7th ed. (pp. 2,980-2,988). Philadelphia, PA: Lippincott, Williams and Wilkins.

J.E.B. v. Alabama, 511 U.S. 127 (1994).

Kapardis, A. (2003). Psychology and Law: A Critical Introduction, 2nd ed. New York: Cambridge University Press.

Kapp, M. B. (1995). Elder mistreatment: Legal interventions and policy uncertainties. Behavioral Sciences and the Law, 13, 365-380.

Kapp, M. B. (2006). Aging and the law. In R. H. Binstock, \& L. K. George (Eds.), Handbook of Aging and the Social Sciences, 6th ed. (pp. 419-435). Amsterdam: Elsevier.

Kemper, S. (1988). Geriatric psycholinguistics: Syntactic limitations of oral and written language. In L. L. Light, \& D. M. Burke (Eds.), Language, Memory, and Aging (pp. 58-76). New York: Cambridge University Press.

Kerbs, J. J. (2000a). The older prisoner: Social, psychological, and medical considerations. In M. B. Rothman, B. D. Dunlop, \& P. Entzel (Eds.), Elders, Crime, and the Criminal Justice System: Myth, Perceptions, and Reality in the 21st Century (pp. 207-228). New York: Springer.

Kerbs, J. J. (2000b). Arguments and strategies for the selective decarceration of older prisoners. In M. B. Rothman, B. D. Dunlop, \& P. Entzel (Eds.), Elders, Crime, and the Criminal Justice System: Myth, Perceptions, and Reality in the 21st Century (pp. 229-250). New York: Springer.

Kim, S. Y. H., \& Appelbaum, P. S. (2006). The capacity to appoint a proxy and the possibility of concurrent proxy directives. Behavioral Sciences and the Law, 24, 469-478.

Kohn, N. A. (2003). Second childhood: What child protection systems can teach elder protection systems. Stanford Law and Policy Review, 14, 175-202.

Lindsay, R. C. L., Brigham, J. C., Brimacombe, C. A. E., \& Wells, G. L. (2002). Eyewitness research. In J. R. Ogloff (Ed.), Taking Psychology and Law Into the Twenty-First Century (pp. 199-223). New York: Kluwer-Plenum.

Lowenstein, A. (2004). Gerontology coming of age: The transformation of social gerontology into a distinct academic discipline. Educational Gerontology, 30(2), 129-141.

Maylor, E. A. (1998). Changes in event-based prospective memory across adulthood. Aging, Neuropsychology, and Cognition, 5(2), 107-128.

McDougall, G. J. (2004). Memory self-efficacy and memory performance among Black and White elders. Nursing Research, 53, 323-331.

McDowd, J. M., \& Craik, F. I. (1988). Effects of aging and task difficulty on divided attention performance. Journal of Experimental Psychology: Human Perception and Performance, $14,267-280$.

McGreevey, J. F. (2005). Elder abuse: The physician's perspective. Clinical Gerontologist, 28, 83-103.

Miller, R. A. (1999). Kleemeier Award Lecture: Are there genes for aging? Journal of Gerontology, 54A, B297-B307.

Morgan, E., Johnson, I., \& Sigler, R. (2006). Public definitions and endorsement of the criminalization of elder abuse. Journal of Criminal Justice, 34, 275-283.

Morrell, R. W., Mayhorn, C. B., \& Bennett, J. (2000). A survey of World Wide Web use in middle-aged and older adults. Human Factors, 42, 175-182.

Morris, R. G., Gick, M. L., \& Craik, F. I. (1988). Processing resources and age differences in working memory. Memory and Cognition, 16, 362-366.

Moskowitz, S. (1998). Saving granny from the wolf: Elder abuse and neglect-the legal framework. Connecticut Law Review, 31, 77-204.

Moye, J. (2000). Mr. Franks refuses surgery. Journal of Aging Studies, 14, 385-402.

National Adult Day Services Association. (2007). Adult Day Care Facilities: The Facts. Retrieved May 17, 2007, from http://www.nadsa.org/adsfacts/default.asp

National Center for Health Statistics. (2005). Health, United States, 2005 with Chart Book on Trends in the Health of Americans. Hyattsville, MD: GPO Stock No. 017-022-01592-7. Retrieved 
May 17, 2007, from http://www.cdc.gov/nchs/products/pubs/pubd/hus/2010/2010. htm\#hus05

Neary, D., \& Snowden, J. S. (2003). Classification of the dementias. In R. C. Tallis, \& H. M. Fillit (Eds.), Brocklehurst's Textbook of Geriatric Medicine and Gerontology, 6th ed. (pp. 775-782). London: Churchill Livingston.

Neuschatz, J. S., Preston, E. L., Burkett, A. A., Toglia, M. P., Lampinen, J. M., Neuschatz, J. S. et al. (2005). The effects of post-identification feedback and age on retrospective eyewitness memory. Applied Cognitive Psychology, 19, 435-453.

Nigro, G., \& Neisser, U. (1983). Point of view in personal memories. Cognitive Psychology, 15, 467- 482.

Nunez, N., McCoy, M. L., Clark, H. L., \& Shaw, L. A. (1999). The testimony of elderly victim/ witnesses and their impact on juror decisions: The importance of examining multiple stereotypes. Law and Human Behavior, 23, 413-423.

Ogloff, J. R. (2002). Two steps forward and one step backward. In J. R. Ogloff (Ed.), Taking Psychology and Law Into the Twenty-First Century (pp. 1-33). New York: Kluwer-Plenum.

O'Rourke, T. E., Penrod, S. D., Cutler, B. L., \& Stuve, T. E. (1989). The external validity of eyewitness identification research: Generalizing across subject populations. Law and Human Behavior, 13, 385-395.

Pakula, M. (2005). The legal responsibility of adult children to care for indigent parents, National Center of Policy Analysis Brief Analysis No. 521, 1-2.

Parkin, A. J., \& Walter, B. M. (1992). Recollective experience, normal aging, and frontal dysfunction. Psychology and Aging, 7, 290-298.

Persons disqualified or excused from jury service. (2006). Florida Statute $§ 40.013$.

Popelka, M. M., Cruickshanks, K. J., Wiley, T. L., Tweed, T. S., Klein, B. E., \& Klein, R. (1998). Low prevalence of hearing aid use among older adults with hearing loss: The epidemiology of hearing loss study. Journal of American Geriatric Society, 46, 1,075-1,078.

Quas, J. A., Goodman, G. S., Ghetti, S., \& Redlich, A. D. (2000). Questioning the child witness: What can we conclude from the research thus far? Trauma, Violence, and Abuse, 1, 223-249.

Rathbone-McCuan, E. (2000). Elder abuse within the context of intimate violence. University of Missouri at Kansas City Law Review, 69, 215-226.

Roebuck, J. (1979). When does 'old age' begin?: The evolution of the English definition. Journal of Social History, 12, 417-428.

Rosenfeld, B. (2004). Assisted Suicide and the Right to Die: The Interface of Social Science, Public Policy, and Medical Ethics. Washington, DC: American Psychological Association.

Ross, D. F., Dunning, D., Toglia, M. P., \& Ceci, S. J. (1990). The child in the eyes of the jury: Assessing mock jurors' perceptions of the child witness. Law and Human Behavior, 14, 5-23.

Rothman, M. B., \& Dunlop, B. D. (2004). Judicial responses to an aging America. Court Review. Retrieved October 30, 2006, from http://www.fiu.edu/ coa/downloads/elder\%20justice/ CourtRevJudicialRtaaA.pdf

Rothman, M. B., Dunlop, B. D., \& Entzel, P. (2000a). Elders, Crime, and the Criminal Justice System: Myth, Perceptions, and Reality in the 21st Century. New York: Springer.

Schacter, D. L., Koutstaal, W., Johnson, M. K., Gross, M. S., \& Angell, K. E. (1997). False recollection induced by photographs: A comparison of older and younger adults. Psychology and Aging, 12, 203-215.

Schoenborn, C. A., Vickerie, J. L., \& Powell-Griner, E. (2006). Health Characteristics of Adults 55 Years of Age and Over: United States, 2000-2003. US Department of Health and Human Services Centers for Disease Control and Prevention. Retrieved October 30, 2006, from http://www.cdc.gov/nchs/data/ad/ ad370.pdf

Sears, D. O. (1986). College sophomores in the laboratory: Influences of a narrow data base on social psychology's view of human nature. Journal of Personality and Social Psychology, 51, 515-530.

Sieniarecki v. Florida, 756 So. 2d 68 (2000). 
Smith, A. D., \& Winograd, E. (1978). Adult age differences in remembering faces. Developmental Psychology, 14, 443-444.

Snapshot. (2003). A Statistical Profile of Older Americans aged 65+. U.S. Department of Health and Human Services Administration on Aging. Retrieved September 28, 2006, from http://www.aoa.gov/press/fact/ fact.asp\#Snapshots

Steffensmeier, D., \& Motivans, M. (2000). Sentencing the older offender: Is there an "age bias"? In M. B. Rothman, B. D. Dunlop, \& P. Entzel (Eds.), Elders, Crime, and the Criminal Justice System: Myth, Perceptions, and Reality in the 21st Century (pp. 185-205). New York: Springer.

Stein, C. H., Wemmerus, V. A., Ward, M., Gaines, M. E., Freeberg, A. L., \& Jewell, T. C. (1998). "Because they're my parents": An intergenerational study of felt obligation and parental caregiving. Journal of Marriage and the Family, 60, 611-622.

Sterns, A. A. (2005). Curriculum design and program to train older adults to use personal digital assistants. Gerontologist, 45(6), 828-834.

Stuart-Hamilton, I. A. (2003). Normal cognitive aging. In R. C. Tallis, \& H. M. Fillit (Eds.), Brocklehurst's Textbook of Geriatric Medicine and Gerontology, 6th ed. (pp. 125-142). London: Churchill Livingston.

Takacs, T. L., \& McGuffey, D. L. (2002). Perspectives on elder law: Medicaid planning: Can it be justified? Legal and ethical implications of Medicaid planning. William Mitchell Law Review, 29, 111-158.

Tenzer, J. (2006). Reaching the final frontiers in Medicaid and managed care. New York University Annual Survey of American Law, 62, 329-368.

Tierney, J. (2004, December 26). Adultescent. The New York Times, p. 4.

Wall, J. (1998). Elder care. Corrections Today, 60, 136-139.

Warner, H. R. (2003). Biology of aging. In R. C. Tallis, \& H. M. Fillit (Eds.), Brocklehurst's Textbook of Geriatric Medicine and Gerontology, 6th ed. (pp. 51-58). London: Churchill Livingston.

Wells, G. L., \& Olson, E. A. (2002). Eyewitness identification: Information gain from incriminating and exonerating behaviors. Journal of Experimental Psychology: Applied, 8, 155-167.

Wells, G. L., Wright, E. F., \& Bradfield, A. L. (1999). Witnesses to crime: Social and cognitive factors governing the validity of people's reports. In R. Roesch, \& S. Hart (Eds.), Psychology and Law: State of the Discipline (pp. 53-87). New York: Plenum.

Wiener, R. L., Winter, R. J., Rogers, M., Seib, H., Rauch, S., Kadela, K., Hackney, A., \& Warren, L. (2002). Evaluating published research in psychology and law: A gatekeeper analysis of Law and Human Behavior. In J. R. Ogloff (Ed.), Taking Psychology and Law Into the Twenty-First Century (pp. 371-405). New York: Kluwer-Plenum.

Wilkins, C. H., \& Birge, S. J. (2005). Prevention of osteoporotic fractures in the elderly. American Journal of Medicine, 118, 1,190-1,195.

Wolf, R. S. (2000). Elders as victims of crime, abuse, neglect, and exploitation. In M. B. Rothman, B. D. Dunlop, \& P. Entzel (Eds.), Elders, Crime, and the Criminal Justice System: Myth, Perceptions, and Reality in the 21st Century (pp. 19-42). New York: Springer.

Yampolskaya, S., \& Winston, N. (2003). Hospice care in prison: General principles and outcomes. American Journal of Hospice and Palliative Care, 20, 290-296.

Yarmey, A. D. (1984). Age as a factor in eyewitness memory. In G. L. Wells, \& E. F. Loftus (Eds.), Eyewitness Testimony (pp. 142-154). Cambridge: Cambridge University Press.

Yarmey, A. D. (2000). The older eyewitness. In M. B. Rothman, B. D. Dunlop, \& P. Entzel (Eds.), Elders, Crime, and the Criminal Justice System: Myth, Perceptions, and Reality in the 21st Century (pp. 127-148). New York: Springer.

Zapf, P. A., Viljoen, J. L., Whittemore, K. E., Poythress, N. G., \& Roesch, R. (2002). Competency: Past, present, and future. In J. R. Ogloff (Ed.), Taking Psychology and Law Into the Twenty-First Century (pp. 171-198). New York: Kluwer-Plenum. 